\title{
STRATEGI PENGEMBANGAN KARAKTER KEDISIPLINAN SISWA MADRASAH ALIYAH NURIDDAHLANI TAROKAN BANYUANYAR PROBOLINGGO
}

\author{
Taufiqurrohman Rifa'i \\ Universitas Islam Zainul Hasan Genggong \\ taufiqurohmanrifai@gmail.com
}

DOI: https://doi.org/10.35719/jieman.v2i2.26

\begin{abstract}
Abstrak
Madrasah berkontribusi dalam mengenalkan, menumbuhkan, memelihara dan meningkatkan nilai-nilai disiplin peserta didik, termasuk kepatuhan terhadap tata tertib madrasah. Selain itu, guru juga mempunyai andil yang besar dalam menumbuhkan sikap disiplin diri kepada peserta didiknya. Penelitian ini dimaksudkan untuk mengungkap strategi serta faktor pendukung dan penghambat pengembangan karakter disiplinan siswa di Madrasah Aliyah Nuriddahlani Tarokan Banyuanyar Probolinggo. Penelitiam ini menggunakan pendekatan kualitatif jenis studi kasus. Data-data diperoleh melalui wawancara, observasi, studi dokumentasi dan studi literatur. Hasil penelitian adalah Pertama, pengembangan karakter disiplin siswa di Madrasah Aliyah Nuriddahlani Tarokan Banyuanyar Probolinggo menggunakan beberapa pendekatan diataranya adalah kegiatan ruitin, kegiatan spontan, kegiatan keteladanan dan kegiatan pengkondisian. Kedua, hambatan yang dihadapi madrasah dalam mengembangkan karakter disiplin siswa terdiri atas: keterlambatan guru sebelum jam pertama, ketergantungan terhadap guru PAI dalam pembacaan do'a di awal dan akhir pelajaran, keterlambatan peserta didik dengan berbagai macam alasan. Solusi dari hambatan itu, kepala madrasah sebagai pimpinan madrasah diharapkan dapat memberikan arahan dan penerangan baik kepada seluruh warga madrasah, motivasi terhadap guru agar datang tepat waktu sehingga sama-sama memperkuat ketertiban dan kedisiplinan serta pelayanan terhadap madrasah, kepala madrasah dapat memberdayakan guru-guru yang lain yang memiliki kompetensi perihal membaca doa agar pelaksanaannya lebih baik, dan perlu sanksi yang telah ditetapkan madrasah kepada peserta didik yang datang terlambat dengan
\end{abstract}


disertai memberikan arahan dan penerangan serta memotivasi mereka agar dapat datang ke madrasah lebih awal.

Kata Kunci: pengembangan karakter disiplin, madrasah aliyah

\section{Abstract}

Madrasahs have such contribution in introducing, establishing, maintaining and enhancing the cdisciplinary values of students, including adherence towards the regulation within madrasah itself. Likewise, teachers also have a big share in fostering an attitude of self-discipline towards their students. This research is intended to reveal the strategies and factors supporting and inhibiting the establishment of disciplinary character of students at Madrasah Aliyah Nuriddahlani Tarokan Banyuanyar Probolinggo. This research uses a qualitative case study type approach. The data were collected through interviews, observation, documentation, and literature study. The results of the study indicate that; First, the development of disciplinary character of students at Madrasah Aliyah Nuriddahlani Tarokan Banyuanyar Probolinggo was done through several approaches, including routine, spontaneous, exemplary, and conditioning activities. Second, the obstacles faced by madrasas in developing the character of students' discipline consisted of: teacher tardiness before the first hour period, the dependence on Islamic education teachers in reciting prayers at the beginning and the end of lessons, students' belatedness for various reasons. The solution to be done are; the head of the madrasah as the principal is expected to provide good direction and enlighten all of the madrasah's members, motivating teachers to arrive on time so that they both strengthen order and discipline as well as provision to madrasah. Moreover, the principals also can empower other teachers who have the competence regarding reading prayers so that the implementation itself is going to be better, and it need sanctions set by the madrasah for students who come late, accompanied by providing direction and motivating them to come to the madrasah earlier.

Keywords: disciplinary values establishment, Madrasah Aliyah

\section{Pendahuluan}

Dalam rangka mencapai sosok manusia yang berdisiplin, madrasah dengan segala upaya hendaknya mampu menciptakan lingkungan yang kondusif bagi tumbuh, berkembang dan meningkatkan nilai disiplin sehingga menjadi disiplin diri (self discipline) dalam perilaku peserta didik. Kedisiplinan dalam proses pendidikan sangat diperlukan karena bukan hanya untuk menjaga kondisi suasana belajar dan mengajar berjalan dengan lancar, tetapi juga untuk menciptakan pribadi yang kuat bagi setiap siswa. Disiplin 
merupakan perasaan taat dan patuh terhadap nilai yang dipercaya termasuk melakukan pekerjaan tertentu yang dirasakan menjadi tanggung jawab. Madrasah telah tumbuh dan berkembang nilai disiplin dalam perilaku peserta didiknya, antara lain terdapatnya perilaku yang patuh pada norma madrasah. Sehubung dengan itu, hasil observasi di Madrasah Aliyah (MA) Nuriddahlani telah menunjukkan adanya bukti bahwa perilaku peserta didik yang kurang disiplin dalam pembelajaran maupun di luar pembelajaran seperti suka ribut di dalam kelas, makan di dalam kelas, tidak memperhatikan guru sedang menjelaskan, berpakaian tidak sesuai dengan ketentuan madrasah, ijin ke kamar mandi tidak kembali lagi ke kelas, pengabaian tugas yang diberikan guru.

Madrasah merupakan institusi pendidikan yang bertanggung jawab terhadap pembentukan karakter disiplin siswa. Oleh karena itu, karakter disiplin tidak hanya tumbuh dan berkembang pada setiap individu manusia, tetapi juga pada organisme atau institusi pendidikan yang disebut madrasah. Karakter siswa tidak mungkin tumbuh dan berkembang jika madrasah tidak berkarakter. Dengan kata lain, hanya pada institusi pendidikan berkarakterlah, peserta didik akan tumbuh dan berkembang sebagai manusia yang berkarakter.

Penelitian yang dilakukan oleh Althof dan Berkowitz menemukan hasil bahwa penerapan program pendidikan karakter di sekolah-sekolah, akan memberikan dampak positif pada kekuatan karakter peserta didik. Sekolah yang melaksanakan program pendidikan karakter telah sukses menumbuhkan perilaku disiplin, meningkatkan kehadiran siswa di sekolah, sedikit siswa yang drop-out, mengurangi kekerasan, intimidasi dan meningkatkan prestasi belajar siswa di sekolah. ${ }^{1}$

Dalam pengembanganya pembinaan karakter disiplin siswa di madrasah tidak terlepas dari peran guru. Guru merupakan contoh dan juga teladan yang menjadi pioneer dalam menumbuhkan disiplin siswa, terutama disiplin diri (selfdiscipline). Guru selain bertugas sebagai pengajar juga memiliki fungsi sebagai motivator dalam membantu peserta didik mengembangkan pola perilakunya, meningkatkan standar perilakunya, dan melaksanakan aturan sebagai alat untuk menegakan disiplin.

${ }^{1}$ Wolfgang Althof and Marvin W. Berkowitz, "Moral Education and Character Education: Their Relationship and Roles in Citizenship Education." Journal of moral education 35.4 (2006): 495-518. 
Penelitian ini dilakukan dengan menggunakan pendekatan kualitatif drngan pendekatan studi kasus. Fokus penelitian ini adalah strategi pengembangan karakter kedisiplinan siswa di MA Nuriddahlani Probolinggo. Secara konseptual dalam penelitian ini, menunjukan Madrasah mempunyai kontribusi dalam mengenalkan, menumbuhkan, memelihara dan meningkat-kan nilai-nilai disiplin peserta didik, termasuk antara lain kepatuhan peserta didik pada tata tertib di madrasah. Selain itu, guru juga mempunyai andil yang besar dalam menumbuhkan sikap disiplin diri kepada peserta didiknya.

\section{Pembahasan}

\section{Strategi Pengembangan Karakter Disiplin Siswa Madrasah Aliyah Nuriddahlani Tarokan Banyuanyar Probolinggo}

Karakter merupakan titisan ilmu pengetahuan dan keterampilan. Pengetahuan tanpa landasan kepribadian yang benar akan menyesatkan, dan keterampilan tanpa kesadaran diri akan menghancurkan. Karakter itu akan membentuk motivasi, yang dibentuk dengan metode dan proses yang bermartabat. Karakter bukan sekedar penampilan lahiriah, melainkan mengungkapkan secara implisit hal-hal yang tersembunyi. Karakter yang baik mencakup pengertian, keperdulain dan tindakan berdasarkan nilainilai etika, serta meliputi aspek kognitif, emosional, dan perilaku dari kehidupan moral. ${ }^{2}$

Pendidikan karakter adalah segala sesuatu yang dilakukan guru, yang mampu mempengaruhi karakter peserta didik. Guru membantu membentuk watak peserta didik. Hal ini mencakup keteladanan bagaimana perilaku guru, cara guru berbicara atau menyampaikan materi, bagaimana guru bertoleransi, dan berbagai hal terkait lainnya. Pendidikan karakter harus diberikan pada pendidikan formal khususnya lembaga pendidikan TK/RA, SD/MI, SMP/MTs, SMA/MA, SMK, MAK dan Perguruan Tinggi melalui pembelajaran dan ekstrakurikuler, penciptaan budaya satuan pendidikan, dan pembiasaan. ${ }^{3}$

Disiplin berarti setiap macam pengaruh yang ditujukan untuk menolong anak mempelajari cara-cara menghadapi tuntutan yang datang dari lingkungannya dan juga cara-cara menyelesaikan

${ }^{2}$ Jamal Ma'mur Asmani, Buku Panduan Internalisasi Pendidikan Karakter di Sekolah (yogyakarta: DIVA Press, 2013), 27.

${ }^{3}$ Daryanto dan Suryatri Darmiatun, Implementasi Pendidikan Karakter di Sekolah (Yogyakarta: Penerbit Gava Media, 2013), 47. 
tuntutan-tuntutan yang mungkin diajukan terhadap lingkungannya. ${ }^{4}$ Soegeng Priyodarminto dalam bukunya Disiplin Kiat Menuju Sukses mendefinisikan sebagi suatu kondisi yang tercipta dan terbentuk melalui proses dari serangkaian perilaku yang menunjukkan nilai-nilai ketaatan, kepatuhan, keteraturan, dan atau ketertiban. ${ }^{5}$

Pengembangan karakter disiplin siswa di MA Tarokan Banyuanyar Probolinggo menggunakan beberapa stretagi, yaitu:

\section{Kegiatan Rutin}

Berdasarkan hasil wawancara dengan kepala madrasah, bentuk kegiatan yang dilaksanakan secara rutin oleh madrasah dalam rangka menanamkan nilai-nilai karakter antara lain:

a. Briefing pagi dan siang

Kepala madrasah berpendapat bahwa brifing pagi sebelum pembelajaran dan siang setelah pembelajaran bermanfaat untuk memberikan informasi laporan terbaru, meneruskan informasi dari Dinas Pendidikan Kabupaten, dan membahas tentang proses pembelajaran. Kepala madrasah dan guru harus datang sebelum pembelajaran dimulai untuk melaksa-nakan briefing pagi dan pulang setelah briefing siang mengandung nilai kedisiplinan dan keteladanan. Sebelum masuk kedalam kelas guru dan kepala madrasah mengadakan briefing pagi untuk menanyakan kesiapan masing-masing guru untuk melaksanakan proses pembelajaran, kemudian berdo'a dan menuju ke kelas masingmasing. Kemudian setelah jam pulang madrasah selesai kepala madrasah dan guru melaksanakan briefing siang sebelum pulang untuk menanyakan proses pembelajaran dalam kelas yang sudah terlaksana dan diakhiri dengan berdo'a.

Selain itu, hal tersebut diperkuat dengan hasil observasi yang peneliti lakukan selama lima kali pengamatan bahwa setiap hari kepala madrasah dan guru melaksanakan briefing pagi yang dimulai dari pukul 06.50 sampai 07.00 WIB. Pada pengamatan I, II dan III, kepala madrasah memimpin do'a guru dan karyawan pada briefing pagi sebelum pelajaran dan siang sesudah pelajaran. Briefing dibuka oleh salah satu guru kemudian kepala madrasah memberikan pengarahan dan pengumuman bila ada,

${ }^{4}$ Alex Sobur, Anak Masa Depan, (Bandung: Angkasa, 1991), 144.

${ }^{5}$ Soejitno Irmim dan Abdul Rochim, Membangun Disiplin Diri Melalui Kecerdasan Spiritual dan Emosional, Jakarta: Batavia Press, 2004), 5. 
di kesempatan ini guru diberikan kesempatan untuk menyampaikan pendapat atau ide. Kepala madrasah selalu memberi motivasi kepada guru pada setiap kesempatan briefing pagi dengan ajakan untuk melaksanakan kewajiban dengan ikhlas. Dilanjutkan do'a bersama kemudian guru menuju ke kelas masing-masing, dengan adanya briefing pagi dan siang maka kepala madrasah dan semua guru harus datang sebelum jam pelajaran dimulai dan pulang pada waktu yang ditentukan.

\section{b. Tugas piket}

Berdasarkan hasil wawancara dengan Kepala Madrasah diperoleh data bahwa tugas piket sudah dijalankan dengan baik. Kepala madrasah berupaya untuk menanamkan kepedulian pada semua guru. Guru piket diberikan kunci ruang guru, maka guru piket tersebut harus berangkat paling pagi, apabila tidak rekan-rekan guru yang lain tidak bisa masuk karena ruangan masih terkunci dan tidak bisa melaksanakan briefing.

Hasil observasi tidak jauh berbeda dengan hasil wawancara kepala madrasah, guru, dan siswa. Pada hasil pengamatan kepala dan guru piket datang lebih pagi dan membuka pintu ruang guru kemudian berdiri di dekat gerbang madrasah untuk menyambut siswa dengan salam dan jabat tangan. Guru piket mengisi buku piket sesuai jadwal setiap harinya, dengan uraian jam datang dan apa saja yang dilakukan selama di madrasah.

c. Mengucapkan salam dan berjabat tangan

Prioritas pertama kepala madrasah untuk dilakukan ialah mengajarkan siswa mengucapkan salam dan berjabat tangan pada guru atau orang yang lebih tua karena dianggap penting dalam pembentukan karakter. Maka, dibuat jadwal piket guru setiap hari agar siap menyambut siswa di gerbang madrasah dengan salam dan jabat tangan. Setiap pagi guru kelas harus siap di pintu kelas masing-masing, sebelum masuk ke dalam kelas siswa dikondisikan berbaris rapi di depan kelas untuk berjabat tangan dengan guru dan masuk ke dalam kelas masingmasing. Pernyataan kepala madrasah tersebut diperkuat dengan pernyataan yang disampaikan oleh guru ketika peneliti mengajukan pertanyaan tentang pendekatan apa yang dilakukan untuk menanamkan karakter dan disiplin siswa. 
Hasil observasi tidak jauh berbeda dengan hasil wawancara kepala madrasah, guru, dan siswa. Pada setiap pagi kepala dan guru sudah berdiri di dalam madrasah untuk menyambut siswa yang datang dengan salam dan jabat tangan, hal ini dilakukan setiap hari bergantian sesuai dengan jadwal piket guru. Pada pengamatan I, II dan III Kepala Madrasah mengucapkan salam dan berjabat tangan pada murid di pagi hari.

Dari hasil wawancara dan observasi di atas, peneliti dapat menyimpulkan bahwa bentuk kegiatan rutin yang dilaksanakan di MA. Nuriddahlani adalah briefing pagi dan siang, tugas piket guru dan siswa, pembiasaan mengucapkan salam dan jabat tangan. Dalam hal ini nilai karakter yang diintegrasikan adalah nilai tanggung jawab dan disiplin. Awalnya meski masih ada guru yang terlambat mengikuti briefing namun secara keseluruhan sudah berjalan dengan baik.

\section{Kegiatan Spontan}

Berdasarkan hasil wawancara dan observasi kegiatan spontan yang dilakukan madrasah yaitu dengan cara mengikuti kegiatan acara nasional dan acara keagamaan yang diselenggarakan oleh madrasah maupun luar madrasah. Kegiatan tersebut antara lain adalah kerja bakti incidental guru dan karyawan melaksanakan kerja bakti dengan membersihkan dan menata kantor guru dalam rangka persiapan semester yang akan datang.

Berdasarkan hasil wawancara dengan kepala madrasah, diperoleh data bahwa kegiatan spontan dilakukan kepala madrasah dan guru dengan selalu memberi contoh yang baik dengan mengenakan seragam dan atribut lengkap seperti bet, pin dsb., apabila ada anak yang kurang rapi anak tersebut didekati lalu dirapikan, contoh ada anak putri dengan rambut panjang yang digerai maka didekati kemudian dirapikan dengan diikatkan rambutnya menggunakan karet gelang, setelah rapi diberitahu besok lagi rambutnya diikat biar rapi.

Kegiatan spontan yang lain adalah memperingatkan siswa yang datang terlambat, mengingatkan siswa untuk tidak menyontek, mengingatkan siswa yang tidak berpakaian rapi, mengoreksi kesalahan yang dilakukan oleh siswa secara spontan dengan membenahi perilaku siswa dari hal-hal yang kecil seperti disiplin dalam menggunakan waktu istirahat, posisi makan yang 
baik, cara berbicara yang sopan, mendo'akan dan atau menjenguk teman yang sakit.

Dari hasil observasi, Kepala madrasah, guru dan siswa selalu mengingatkan warga madrasah yang tidak berpakaian rapi. Kepala madrasah mengingatkan siswa yang berpakaian tidak rapi, mengajarkan siswa putri untuk mengikat rambut. Pada pengamatan guru menegur siswa yang tidak berpakaian rapi seperti baju yang tidak dimasukkan agar merapikan pakaianya. Siswa mengingatkan teman yang berpakaian tidak rapi.

Madrasah telah menerapkan sistem disiplin dan diterapkan dengan baik. Kepala madrasah memanggil siswa yang terlambat sebanyak 3x dan orang tuanya akan dipanggil. Kepala madrasah memanggil siswa yang terlambat saat upacara agar melapor ke guru kelas dan dicatat. Siswa yang datang terlambat ditanya oleh guru alasan kenapa datang terlambat dan dinasehati agar lain kali tidak terlambat, apabila 3 kali berturut-turut datang terlambat maka orang tua siswa tersebut akan dipanggil ke madrasah.

Kepala madrasah selalu menekankan bahwa peserta didik jangan disalahkan, karena kesalahan anak bukan sepenuhnya tanggung jawab dia sendiri namun juga tanggung jawab keluarga, lingkungan dan pendidik. Mengajarkan hal-hal yang sederhana seperti apabila berjabat tangan harus melihat kepada yang dijabat tangan, apabila makan hendaknya sambil duduk, dan mendekati anak dengan kasih sayang maka masalah anak akan keluar dengan sendirinya.

Dari hasil wawancara dan observasi di atas, peneliti dapat menyimpulkan bahwa kegiatan spontan yang dilakukan oleh kepala madrasah dan guru antara lain memperingatkan siswa yang datang terlambat, mengingatkan siswa untuk tidak menyontek, mengingatkan siswa yang tidak berpakaian rapi, mengoreksi kesalahan yang dilakukan oleh siswa secara spontan dengan membenahi perilaku siswa dari hal-hal yang kecil seperti disiplin dalam menggunakan waktu istirahat, posisi makan yang baik dan cara berbicara yang sopan. Nilai yang diangkat adalah religius, disiplin dan toleransi.

\section{Keteladanan}

Kepala madrasah, guru, dan karyawan berusaha menjadi model karakter bagi siswa baik dalam kerapian diri, kedisiplinan, serta menaati peraturan madrasah. Kepala madrasah juga memberikan teladan bagi guru, karyawan, siswa dan bahkan 
orangtua/wali dengan cara mengedepankan sikap disiplin dan tegas dalam hal waktu, kepala madrasah sering datang paling pagi dan pulang paling akhir, tertib administrasi dengan membuat buku harian kepala madrasah, dan atribut yang dikenakan seperti topi, bet, name take.

Pernyataan kepala madrasah tersebut diperkuat dengan pernyataan yang disampaikan oleh guru ketika peneliti mengajukan pertanyaan pada guru tentang apakah guru konsisten dengan taat terhadap peraturan madrasah.

Dari hasil observasi, peneliti memperoleh data bahwa kepala madrasah dan guru memakai seragam dinas pada hari Senin, memakai seragam hijau pada hari Selasa, memakai batik pada hari Rabu dan Kamis, serta memakai pakaian polos yang bebas dan rapi pada hari Sabtu dan Ahad. Peneliti menemukan data bahwa kepala madrasah selalu mengenakan atribut lengkap.

\section{Pengkondisian}

Berdasarkan hasil wawancara dengan kepala madrasah, diperoleh data bahwa kepala madrasah membiasakan guru dan siswa untuk menaati tata tertib madrasah. Selain itu, kepala madrasah mendukung kegiatan ekstrakurikuler. Pernyataan tersebut diperkuat dengan pernyataan yang disampaikan oleh guru sebagai berikut. menyatakan "Dorongan dan motivasi kepala madrasah terhadap guru tinggi sekali, datang paling awal dan pulang paling akhir memberi contoh yang baik dan mendorong guru untuk selalu menjalankan kewajiban, tertib dalam administrasi, dan mengembangkan IPTEK.

Dari hasil observasi menunjukkan bahwa data yang tidak jauh berbeda, kepala madrasah dan guru menempelkan tata tertib madrasah, menyediakan fasilitas dan menempel slogan sebagai usaha dalam melakukan pengkondisian siswa. Peneliti menamukan tata tertib madrasah di tempel di ruang kelas, ruang guru dan kepala madrasah.

Peneliti menemukan bahwa serok sampah, bak sampah, sapu, kemoceng, penghapus tersedia di setiap kelas dan di gunakan dengan baik oleh siswa ketika melaksanakan tugas piket. Sloganslogan pendidikan karakter juga tersebar di setiap sudut madrasah. Kepala Madrasah dan guru juga memasang tagline nilai karakter area bebas asap rokok, jagalah kebersihan, jujur pasti prestasi tinggi, kebersihan pangkal kesehatan, rajin pangkal pandai, ayo jangan buang sampah sembarangan, aku anak sehat, setelah buang 
air kecil/besar harap disiram air secukupnya terimakasih. Jagalah sopan santun di lingkungan madrasah 3 B: berpakaian, berbicara, bersikap, tujuh K: keamanan, kebersihan, ketertiban, keindakan, kerindangan, kekeluargaan, keselamatan. Di dalam setiap kelas terdapat foto presiden dan wakil presiden, lambang garuda, gambar tokoh nasional dan tokoh pewayangan. Terdapat papan mading (majalah dinding) di beberapa tempat yang berisi karya siswa.

Beberapa bentuk pembiasaan lain yang guru tanamkan dalam rangka menanamkan nilai-nilai karakter kepada siswa diantaranya membiasakan infak, peduli terhadap lingkungan, datang lebih awal ketika piket. Berdasarkan hasil observasi yang peneliti lakukan, diperoleh data bahwa sepulang madrasah masingmasing siswa kelas I menaikkan kursi ke atas meja. Siswa kelas II menaikkan bangku ke atas meja. Siswa kelas III menaikkan kursi ke atas meja berlaci dua.

Madrasah menyediakan alat kebersihan seperti sapu serok sampah, kemoceng dan penghapus di tiap kelas. Tempat sampah juga disediakan di tiap kelas berwarna hijau dan beberapa sudut madrasah berwarna merah, kuning dan hijau. Pot tanaman juga disediakan di depan tiap kelas, tempat cuci tangan di beberapa sudut madrasah, serta air yang lancar dan kamar mandi yang cukup bersih berlantai keramik.

Berdasarkan hasil wawancara dan observasi dapat ditarik kesimpulan bahwa upaya pengondisian menerapkan nilai tanggung jawab dan disiplin yang dilakukan yaitu dengan menegakkan tata tertib dan menjaga kebersihan lingkungan madrasah. Setiap ruang di MA. Nuriddahlani seperti ruang guru dan karyawan, ruang kepala madrasah, ruang kelas, ruang UKS, ruang perpustakaan dan ruang serba guna terdapat tata tertib madrasah dan slogan karakter, secara fisik sudah berlantaikan keramik dan mudah dibersihkan. Pengkondisian dirasa belum maksimal diterapkan karena tagline yang ada sudah banyak yang usang dan berdebu sudah harus diganti dengan yang baru dan isi mading sudah lama tidak diperbaharui.

Temuan ini sejalan dengan pendapat Eka Prihatin. ${ }^{6}$ Menurutnya, cara-cara penanggulangan pelanggaran disiplin dilaksanakan secara bertahap dengan tetap memperhatikan jenis gangguan yang ada dan siapa pelakunya, apakah dilakukan oleh individu atau kelompok. Langkah tersebut mulai dari tahapan

\footnotetext{
${ }^{6}$ Eka Prihatin, Management Peserta Didik, (Bandung: Alfabeta, 2011), 93.
} 
pencegahan sampai pada tahap penyembuhan, dengan tetap bertumpu penekanan substansinya bukan pada pribadi peserta didik. Di samping itu juga harus tetap menjaga perasaan kecintaan terhadap peserta didik bukan karena rasa benci atau emosional.

Ada tiga jenis teknik pembinaan disiplin kelas. Pertama, teknik inner control. Teknik ini sangat disarankan untuk digunakan guru-guru dalam membina disiplin peserta didiknya. Teknik menumbuhkan kepekaan/ penyadaran akan tata tertib pada akhirnya disiplin bisa tumbuh dan berkembang dari dalam diri peserta didik itu sendiri (self discipline). Dengan kata lain peserta didik diharapkan dapat mengendalikan dirinya sendiri.

Kedua, teknik external control, yaitu mengendalikan diri dari luar berupa bimbingan dan penyuluhan. Teknik ini dalam menumbuhkan disiplin cenderung melakukan pengawasan (yang kadang perlu diperketat dan kalau perlu menjatuhkan hukuman terhadap setiap pelanggaran).

Ketiga, teknik cooperative control. Dengan teknik ini, pembinaan disiplin kelas dilakukan dengan bekerja sama guru dengan peserta didik dalam mengendalikan situasi kelas ke arah terwujudnya tujuan kelas yang bersangkutan. Dimana guru dengan peserta didik saling mengontrol satu sama lain terhadap pelanggaran tata tertib. Yang perlu diperhatikan oleh guru dalam proses pembinaan disiplin kelas adalah pembedaan-pembedaan individual peserta didik dalam kesanggupan mengadakan mawas diri (introspeksi diri) dan pengendalian dirinya (self control). Karena itu teknik cooperative control sangat dianjurkan untuk menetralisir teknik inner control (yang menuntut kedewasaan) eksternal control (yang menganggap peserta didik belum dewasa).

Lebih lanjut Prihatin mengatakan, sekolah yang tertib, aman dan teratur merupakan persyaratan agar siswa dapat belajar secara optimal. Kondisi semacam ini bisa terjadi jika disiplin di sekolah berjalan dengan baik. Kedisiplinan peserta didik dapat ditumbuhkan jika iklim sekolah menunjukkan kedisiplinan. Siswa baru akan segera menyesuaikan diri dengan situasi di sekolah. Jika situasi sekolah disiplin, siswa akan ikut disiplin. ${ }^{7}$

Hambatan dan Solusi Pengembangan Karakter Disiplin Siswa MA Nuriddahlani Tarokan Banyuanyar Probolinggo

${ }^{7}$ Eka Prihatin, 93. 
Masalah pendidikan adalah merupakan masalah yang berhubungan langsung dengan hidup dan kehidupan manusia. Pendidikan merupakan usaha dari manusia dewasa yang telah sadar akan kemanusiaannya dalam membimbing, melatih, mengajar dan menanamkan nilai-nilai serta dasar-dasar pandangan hidup kepada generasi muda, agar nantinya menjadi manusia yang sadar dan bertanggungjawab akan tugas-tugas hidupnya sebagai manusia, sesuai dengan sifat hakekat dan ciri-ciri kemanusiaannya. ${ }^{8}$

Secara umum faktor pendukung kegiatan madrasah dalam pengem-bangan karakter disiplin siswa di MA. Nuriddahlani Tarokan Banyuanyar Probolinggo, adalah: (1) madrasah dapat berkembang dengan baik melalui budaya madrasah yang mendukung. Pembentukan budaya madrasah (school culture) sebagai faktor pengembangan karakter disiplin siswa di MA. Nuriddahlani Tarokan Banyuanyar Probolinggo dilakukan melalui serangkaian kegiatan: perencanaan, pelaksanaan pembelajaran yang lebih berorientasi pada peserta didik, dan penilaian yang bersifat komprehensif.

Perencanaan di tingkat madrasah adalah melakukan penguatan dalam penyusunan kurikulum di tingkat madrasah, seperti menetapkan visi, misi, tujuan, struktur kurikulum, kalender akademik, penyusunan silabus dan rencana pelaksanaan pembelajaran (RPP). Keseluruhan perencanaan madrasah yang bertitik tolak dari melakukan analisis kekuatan dan kebutuhan madrasah ternyata dapat menghasilkan program pendidikan yang lebih terarah yang tidak semata-mata berupa penguatan ranah pengetahuan dan keterampilan melainkan juga sikap perilaku yang akhirnya dapat membentuk akhlak budi luhur; (2) Penerapan karakter disiplin siswa dengan pendekatan belajar aktif juga memperoleh dukungan berupa kebijakan, dana, pelatihan, sarana dan prasarana dari komite satuan pendidikan, masyarakat sekitar, orang tua peserta didik, alumni, dan pemerintah daerah; dan (3) madrasah mendapatkan program pendam-pingan yang baik dari Pusat krikulum dan perbukuan (Puskurbuk) kementerian pendidikan Nasional sejak tahun pelajaran 2019/2020.

Berdasarkan hasil penelitian yang dilakukan tentang pengembangan karakter disiplin siswa di MA. Nuriddahlani

8 Zuhairini dkk., Filsafat Pendidikan Islam, (Jakarta: Bumi Aksara, 1989),10 
Tarokan Banyuanyar Probolinggo hampir tidak memiliki hambatanhambatan yang berarti. Beberapa hambatan secara mikro yaitu:

Pertama, hanya terjadi pada kegiatan bersalaman pada pagi hari, dimana beberapa guru yang memperoleh tugas kadangkadang hadir setelah pukul 07.15 pagi sedemikian guru yang bersangkutan kurang dapat menyalami peserta didik yang datang sebelum pukul 07.15 pagi, karena berdasarkan pengamatan hampir sebagian besar peserta didik datang tepat waktu 15 menit sebelum kegiatan pembelajaran dimulai;

Kedua, kehadiran beberapa guru piket yang terkadang hadir diantara pukul 07.15 samapai 07.30. Padahal, guru piket harus hadir pukul o7.0o sesuai komitmen yang telah disepakati madrasah sehingga kontribusinya terhadap ketertiban dan kedisiplinan serta pelayanan terhadap madrasah pada kegiatan awal sebelum dilaksanakan pembelajaran pada jam pertama menjadi kurang optimal;

Ketiga, ketika proses pembacaan doa di awal kegiatan pembelajaran dan di akhir pembelajaran yang hanya dilakukan oleh guru agama, terkadang kurang efisien, mengingat kesibukan jam mengajar guru agama yang cukup tersebar yaitu mengajar pada jam pertama dan pada jam terakhir; dan

Keempat, hampir setiap hari masih ditemui beberapa peserta didik yakni sekitar satu sampai tiga orang yang terlambat karena alasan yang cukup beragam misalnya karena bangun kesiangan, macet, jarak rumah yang terlalu jauh dengan madrasah dan lain sebagainya yang secara realistis alasan yang disampaikan masih realistis.

Solusi dari hambatan yang diperoleh dari hasil penelitian, diperoleh beberapa solusi yang diberikan untuk mengatasi hambatan yang dihadapi oleh madrasah dalam mengembangkan karakter disiplin siswa.

Pertama, kepala madrasah sebagai pimpinan madrasah diharapkan dapat memberikan arahan dan penerangan baik secara langsung bertatap muka di ruang kepala madrasah dengan guru yang bersangkutan sesuai kaidah kemitraan atau secara persuasif kepada guru yang bertugas pada pagi hari agar dapat datang tepat waktu sehingga dapat memberikan pelayanan dan menjalankan tugas yang diamanatkan madrasah dengan baik.

Kedua, solusi terhadap hambatan akan kehadiran beberapa guru piket yang terkadang hadir diantara pukul 07.15 samapai 07.30, padahal seharusnya guru piket harus hadir pukul 07.00 sesuai 
komitmen yang telah disepakati madrasah adalah diharapkan kepala madrasah yang memiliki kemampuan untuk mempengaruhi, mendorong, menggerakkan, mengarah-kan dan memberdayakan (kemampuan $5 \mathrm{M}$ ) dapat memotivasi guru agar memiliki semangat untuk datang ke madrasah tepat waktu sehingga kontribusinya terhadap ketertiban dan kedisiplinan serta pelayanan terhadap madrasah pada kegiatan awal sebelum dilaksanakan pembelajaran pada jam pertama menjadi optimal.

Ketiga, solusi terhadap hambatan ketika proses pembacaan doa di awal kegiatan pembelajaran dan di akhir pembelajaran yang hanya dilakukan oleh guru agama yang ternyata terkadang kurang efisien, mengingat kesibukan jam mengajar guru agama yang cukup tersebar yaitu mengajar pada jam pertama dan pada jam terakhir adalah diharapkan kepala madrasah dapat memberdayakan guruguru yang lain yang memiliki kompetensi perihal membaca doa agar pelaksanaannya lebih baik dan profesional dan atau dapat pula memberdayakan guru piket atau wakil kepala madrasah urusan kesiswaan yang memiliki beberapa staf sedemikian sehingga tidak mesti atau tidak harus selalu guru agama yang membaca doa di awal kegiatan pembelajaran dan doa di akhir pembelajaran.

Keempat, solusi untuk menangani adanya beberapa peserta didik yakni sekitar satu sampai tiga orang yang masih datang terlambat karena alasan yang cukup beragam misalnya karena bangun kesiangan, macet, jarak rumah yang terlalu jauh dengan madrasah dan lain sebagainya adalah dengan tetap menerapkan sanksi yang telah ditetapkan madrasah kepada peserta didik yang datang terlambat dengan disertai memberikan arahan dan penerangan serta memotivasi mereka agar dapat datang ke madrasah lebih awal.

Hal ini sejalan dengan pandangan Agus Wibowo. Menurutnya, untuk mendukung keberhasilan pendidikan karakter, perlu dilakukan sosialisasi tentang moral dasar yang perlu dimiliki anak dan remaja untuk mencegah remaja melakukan kejahatan yang dapat merugikan diri remaja itu sendiri maupun orang lain. Melalui pendidikan karakter akan tertanam nilai-nilai karakter yang baik di dalam diri individu. Nilai-nilai karakter yang baik akan menuntun seseorang dalam berperilaku sehari-hari. Pendapat tersebut senada dengan yang disampaikan Wibowo bahwa pendidikan karakter merupakan proses pendidikan yang menanamkan dan mengembangkan karakter-karakter luhur kepada anak didik, sehingga mereka memiliki karakter luhur, dan 
menerapkan serta mempraktikan dalam kehidupannya, baik di lingkungan keluarga, warga masyarakat, maupun warga negara. ${ }^{9}$

\section{Simpulan}

Pertama, pengembangan karakter disiplin siswa di Madrasah Aliyah Nuriddahlani Tarokan Banyuanyar Probolinggo menggunakan beberapa pendekatan diataranya adalah kegiatan ruitin, kegiatan spontan, kegiatan keteladanan dan kegiatan pengondisian. Kedua, hambatan yang dihadapi madrasah dalam mengembangkan karakter disiplin siswa terdiri atas: keterlambatan guru sebelum jam pertama, ketergantungan terhadap guru PAI dalam pembacaan do'a di awal dan akhir pelajaran, keterlambatan peserta didik dengan berbagai macam alasan. Solusi dari hambatan itu, kepala madrasah sebagai pimpinan madrasah diharapkan dapat memberikan arahan dan penerangan baik kepada seluruh warga madrasah, motivasi terhadap guru agar datang tepat waktu sehingga sama-sama memperkuat ketertiban dan kedisiplinan serta pelayanan terhadap madrasah, kepala madrasah dapat memberdayakan guru-guru yang lain yang memiliki kompetensi perihal membaca doa agar pelaksanaannya lebih baik, dan perlu sanksi yang telah ditetapkan madrasah kepada peserta didik yang datang terlambat dengan disertai memberikan arahan dan penerangan serta memotivasi mereka agar dapat datang ke madrasah lebih awal.

\section{Referensi}

Althof, Wolfgang, and Marvin W. Berkowitz, "Moral education and character education: Their relationship and roles in citizenship education." Journal of moral education 35.4 (2006): 495-518.

Asmani, Jamal Ma'mur, Buku Panduan Internalisasi Pendidikan Karakter di Sekolah, Yogyakarta: DIVA Press, 2013.

Daryanto dan Suryatri Darmiatun, Implementasi Pendidikan Karakter di Sekolah, Yogyakarta: Penerbit Gava Media, 2013

9 Agus Wibowo, Pendidikan Karakter, Strategi membagun Karakter Bangsa Berperadapan (Yogjakarta: Pustaka Pelajar, 2012), 36. 
JIEMAN: Journal of Islamic Educational Management

Irmim, Soejitno, dan Abdul Rochim, Membangun Disiplin Diri Melalui Kecerdasan Spiritual dan Emosional, Jakarta: Batavia Press, 2004.

Prihatin, Eka, Manajemen Peserta Didik, Bandung: Alfabeta, 2011.

Sobur, Alex, Anak Masa Depan, Bandung: Angkasa, 1991.

Wibowo, Agus. Pendidikan Karakter, Strategi membagun Karakter Bangsa Berperadapan, Yogjakarta: Pustaka Pelajar, 2012.

Zuhairini dkk., Filsafat Pendidikan Islam, Jakarta: Bumi Aksara, 1989. 